Informatika i sistemy upravleniya. - 2016. - No. 1(47). - P.106-116.

Eremin E.L. (ereminel@mail.ru)

Amur state university

\title{
ROBUST REGULATOR FOR NONAFFINE NON-STATIONARY PLANTS
}

This paper presents the development of the robust law in conditions of priori uncertainty. The robust law is used for a single-channel nonaffine non-stationary plant that can be affected by parametrical and external hindrances. The solution of synthesis problems leans on application of hyperstability criterion, $L$-dissipativity conditions, as well as usage of a filter-corrector and explicit standard with two outputs in control system.

Keywords: Nonaffine nonlinear systems, the filter-corrector, robust algorithm, reference model, $L$ dissipativity, hyperstability.

DOI: $10.22250 /$ isu.2016.47.106-116

For citation:

Eremin E.L. ROBUST REGULATOR FOR NONAFFINE NON-STATIONARY PLANTS // Informatika i sistemy upravleniya. - 2016. - No. 1(47). - P.106-116. 